\title{
PARTIAL PILOT TESTING RESULTS OF THE NEW CONCEPT OF TECHNICAL EDUCATION AT LOWER SECONDARY SCHOOLS IN THE CZECH REPUBLIC
}

\author{
Jiří DOSTÁL*, Pavlína ČÁSTKOVÁ, Miroslav JANU, Radim DĚRDA, \\ Michal MRÁZEK, Hana BUČKOVÁ \\ Univerzita Palackého v Olomouci, Česká republika
}

Přijato: 16. 2. 20XX / Akceptováno: 25. 5. 20XX

Typ článku: Teoretická studie

DOI: $10.5507 /$ pdf.15.2444XXXX

Abstract: The paper presents partial results of the pilot testing of the newly formulated learning outcomes in technical education by relying on recently created methodological materials. Stemming from a direct contact with the school practice, the paper answers the question of whether the new concept of developing technical thinking, technical creativity, and practical activities proposed for lower secondary schools corresponds with the possibilities of schools, teachers, and especially students. The authors argue that the schools that participated in the research are not willing to implement all learning outcomes in the same extent. Furthermore, the willingness of a particular school to implement these outcomes reflects not only its material resources but also its philosophy of education, opinions and decisions of the school authority, and respective human resources-the presence or the absence of a qualified teacher.

Key words: pilot testing, technology, lower secondary education. 


\section{DÍLČÍ VÝSLEDKY PILOTNÍHO OVĚŘOVÁNÍ NOVÉHO POJETÍ TECHNICKÉHO VZDĚLÁVÁNÍ NA ZÁKLADNÍCH ŠKOLÁCH V ČESKÉ REPUBLICE}

Abstrakt: Př́spěvek predstavuje dilči výsledky pilotního ověrování nově formulovaných očekávaných výstupi učení s využitím inovativně pojatých metodických materiálů. Na základě prímého kontaktu se školni praxi dává odpověd' na to, zda koncepce rozvoje technického myšlení, technické tvořivosti a praktických činností rozpracovaná pro druhý stupen̆ základnich škol skutečně odpovidá možnostem škol, vyučujicich a předevšim žákỉ. Bylo zjištěno, že ne všechny očekávané výsledky jsou školy ochotny realizovat ve stejné míre. Ukázalo se, že ochota škol odráži nejen materiální zabezpečení, které má škola k dispozici, ale i nastavenou filozofii vzděláváni školy, názory a rozhodnutí zřizovatele, a též rovinu lidských zdrojü - konkrétně prítomnost či nepritomnost aprobovaného učitele.

Klíčová slova: pilotní ověrování, technika, základní školy.

*Autor pro korespondenci: j.dostal@upol.cz 


\section{1 Úvod - význam pilotního ověřování}

Jakékoliv inovace nelze realizovat bez patřičného ověření v praxi, tím spí̌e, jedná-li se o modernizaci kurikulárního dokumentu, kterým se ř́íí cca 4200 základních škol v České republice. Proto ministerstvo školství umožnilo realizovat pilotní ověřování, o kterém jsme již informovali (Dostál, 2019), a jehož cílem bylo:

- zapojit do prrípravy nové vzdělávací oblasti veřejnost - odbornou (učitele, ředitele škol...) i laickou;

- otestovat přímo ve školní výuce, zda koncepce rozvoje technického myšlení, technické tvořivosti a praktických činností rozpracovaná pro druhý stupeň základních škol skutečně odpovídá možnostem škol, vyučujících a především žáků;

- oveřit metodické postupy a materiály a na základě zpětné vazby od učitelů a ředitelů škol kvalifikovaně určit, zda a jak přispívají k dosahování očekávaných výstupů učení;

- propojit všechny zainteresované jedince a sdílet jimi vytvořené náměty na výuku.

Ověřování v roce 2019/20 realizoval NPI ČR a probíhalo ve spolupráci s pilotními školami a pedagogickými fakultami. Východiskem se stala nejen podkladová studie (Dostál, 2018), ale i jednání se zástupci škol, odbornou i laickou veřejností a taktéž poznatky obsažené v řadě odborných publikací, viz např. Dixon, R. A. (2013), Dostál, J. (2019), Kropáč, J. (2004). Dostál, J. (2017), Hallström, J., Hultén, M, Lövheim, D. (2013). Dostál, J. (2018), Dostál, J., Hašková, A., Kožuchová, M., Kropáč, J., Duriš, M., Honzíková, J., Částková, P., Žilková, K., Stebila, J., Uhrinová, M., Bendík, M., Fadrhonc, J. (2017), Ingerman, A., Collier-Reed, B. I. (2011).

\section{Charakteristika pilotních škol}

Z hlediska materiálního vybavení byly do pilotního ověřování zahrnuty jednak excelentně vybavené školy, ale taktéž školy s vybavením i několik desetiletí starým, pouze částečně inovovaným, s cílem udržet základní funkčnost dílny. Jedna škola pilotně testovala i v podmínkách bez existence vlastní školní dílny.

V této souvislosti se naskýtá otázka, $\mathrm{v}$ jakých podmínkách probíhá výuka učiva o technice napříč republikou. Na základě dlouhodobého pozorování a konferenčních diskusí pracovníků kateder připravujících učitele techniky (př́íp. technické výchovy, praktických činností nebo pracovního vyučování) je možné uvést, že v České republice je cca $1 / 3$ škol vybavena modernizovanými dílnami, z nichž některé jsou na nejvyšší úrovni v porovnání s celým světem, dále $1 / 3$ škol má standardně vybavenou dílnu, která je mnohdy s původním vybavením (zejména pracovní stoly), avšak v př́ípadě závad bylo pružně reagováno (dílny jsou tak plně funkční) a lze v nich i z dnešního pohledu realizovat kvalitní výuku a úspěšně dosahovat nově formulovaných očekávaných výstupů učení. Poslední třetina je představována školami, které bud' dílnu zrušily nebo dílnu mají, její funkčnost je však po technické stránce limitovaná. $\mathrm{S}$ touto skutečností bylo pracováno i v rámci pilotního ověřování - bylo studováno, jak se školy vyrovnají s realizací výuky zaměřené na nejmodernější technologie (např. laser, $\mathrm{CNC}$, konstrukční robotika, výroba s využitím 3D tisku...). 
Pilotním ověrováním bylo zjištěno, že vybavení školy hraje významnou roli, nicméně není limitujícím faktorem, který by zásadně znemožňoval naplňování očekávaných výsledků učení. Kupř. žák ze základní školy Šumavská v Šumperku vyhrál národní soutěž TechnoChallenge, viz zpráva Šumpersko.net (2019). Zájemce, kteří chtějí získat více informací o soutěži, odkazujeme na webové stránky katedry (KTEIV, 2020).

Pilotní školy se nacházely $\mathrm{v}$ různých regionech s odlišnými podmínkami - různé socioekonomické podmínky žáků, školy městské x vesnické, aprobovaný učitel $\mathrm{x}$ neaprobovaný učitel, školy s dlouhou tradicí x školy relativně nové. Toto bylo záměrem, abychom získali poznatky z co nejvíce možných př́ípadů realizace technického vzdělávání. Školní vzdělávací programy byly navrženy plně v souladu s principem zachování autonomie pilotních škol. Zcela byly respektovány místní podmínky a školy tak ověřovaly v rámci výuky, která odpovídala jejich potřebám. Při následné analýze toho, ve kterých konkrétních ročnících ověřování očekávaných výsledků učení probíhalo, lze uvést zjištění, že pilotní výuka byla $v$ průměru rovnoměrně rozvrstvena mezi jednotlivé ročníky druhého stupně základních škol. Některé školy ověrovaly pouze ve vybraných ročnících, jiné ve všech.

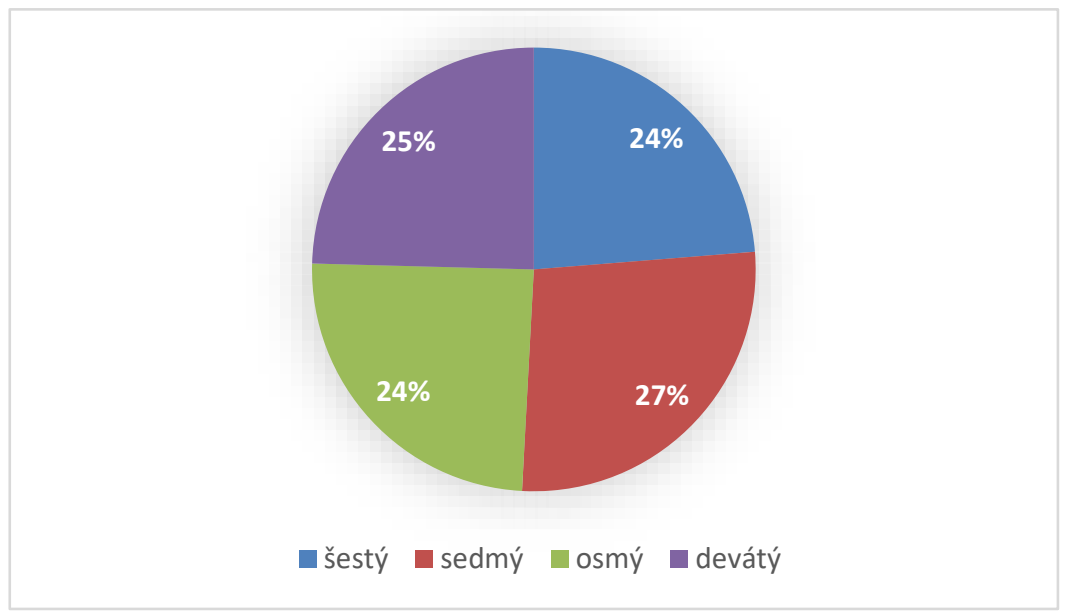

Graf.č.1: přehled ročnikư, kde probihala pilotni výuka

Téměř všechny školy vlastnily dílnu pro realizaci technického vzdělávání. Na čem se zástupci škol shodovali, je skutečnost, že je třeba s ohledem na technologický rozvoj dílny inovovat, což vnímají jako kontinuální proces. Nikdy totiž nelze přerušit vybavování nejnovější technikou, príistroji a zařízením. Existence školních dílen na některých pilotních školách sahá až do 60. let minulého století. Od té doby školní dílny prošly několika vlnami inovací, zejména v souvislosti s rozvojem miniaturizace výrobních strojů a elektronizace. Aktuálně jsou v celé ČR dílny inovovány nebo zcela nově budovány pod vlivem robotizace, automatizace a průmyslu 4.0. 
Plných $74 \%$ pilotních škol je názoru, že dílna není vybavena adekvátně vzhledem $\mathrm{k}$ aktuálním vzdělávacím potřebám a novým trendům. Je pozitivní, že se nejedná o nepromyšlené sdělení, jelikož školy mají poměrně jasnou představu, do čeho konkrétně by chtěly investovat. Nejčastěji uvádějí potřebu pořízení 3D tiskárny, nových pracovních stolů, interaktivní tabule/displeje do dílny, CNC strojů, robotických stavebnic, mikropájek, gravírovacích per, řezbářských dlát, laserové řezačky a gravírky, aku nářadí nebo elektrické lupénkové pily.

Školy, které v poslední době provedly komplexní inovaci učebny pro předmět Technika, realizovaly financování převážně z regionálních operačních programů. Středně rozsáhlé inovace byly prováděny $z$ tzv. výzvy 57 . Dílčí nákupy školy realizují z prostředků zřizovatele nebo rozpočtových prostředků školy.

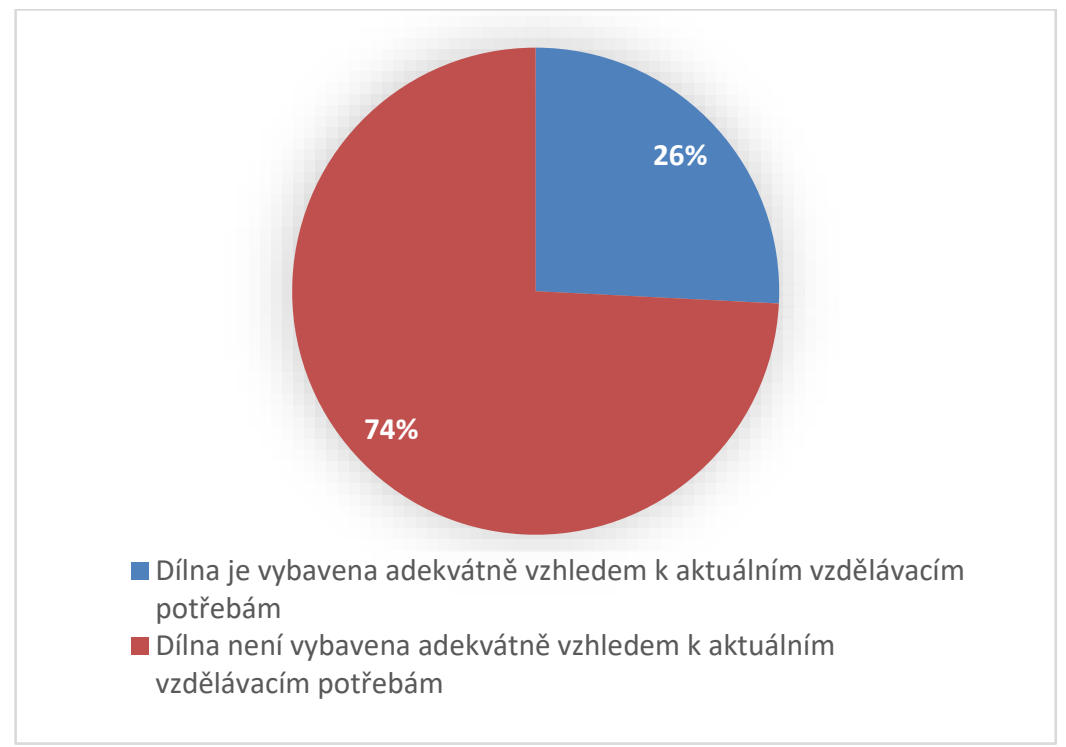

Graf č. 2: Vybaveni školnich dỉlen na pilotnich školách

Nezainteresovaný čtenář se začne ptát, jakým způsobem školy naplňují očekávané výsledky učení, pokud nejsou dílny zcela v souladu s aktuálními trendy. Tento handicap překonávají využíváním dílen spolupracujících stř̌edních škol nebo polytechnických center (např. v Praze existují tzv. polytechnická hnízda, viz Šetlík, 2019). Taktéž navštěvují popularizační centra zaměřená na techniku (veřejné dílny) - např́klad PrůšaLab, TechnoLab, Techmania a další. Zde jsou žáci seznamováni zejména s nejmodernějšími technologiemi.

Materiál na výrobky žáků převážně pořizují $\mathrm{z}$ vlastních rozpočtů (v průměru je cca vynakládáno $100 \mathrm{Kč}$ na žáka/rok). Taktéž jsou využívány sponzorské dary. Některý materiál si pořizují žáci z vlastních prostředkủ. 
Vyučovací předměty, kde pilotní výuka zaměřená na rozvoj technické tvořivosti a technického myšlení probíhala, jsou dlouhodobě ustálené a svébytné. Nesou různé názvy - Pracovní vyučování, Praktické činnosti, Technické činnosti, Pracovní činnosti. Obecně platí, že se školám doporučuje pro předmět užívat název Technika.

\section{Průběh pilotního ověřování, ověřované očekávané výstupy učení a individuální plány ověřování}

Primární byl návrh sady ověřovaných očekávaných výstupů učení. Ten prošel čtyřmi koly vnitřního oponentního řízení, což však bylo nedostatečné s ohledem na implementaci $\mathrm{v}$ rámci inovačních procesů RVP ZV. Proto bylo přistoupeno k získání zpětné vazby přímo ze škol, konkrétně čtyřiceti.

Návrh ověřovaných očekávaných výstupů učení v rámci znalostní kontinuity vycházel z aktuální školní reality ovlivňované současně platným RVP ZV. V této návaznosti byly do návrhu promítnuty perspektivní vize technického rozvoje 21 . století. Cílem bylo získat poznatky o tom, co ve školách vyučovat, ale i jaké učivo redukovat. Ověřované očekávané výsledky učení byly v souladu s potřebami pilotního ověřování (nikoliv návrhu nového pojetí RVP) členěny do 4 tematických celků, jelikož jsme potřebovali získat maximum informací.

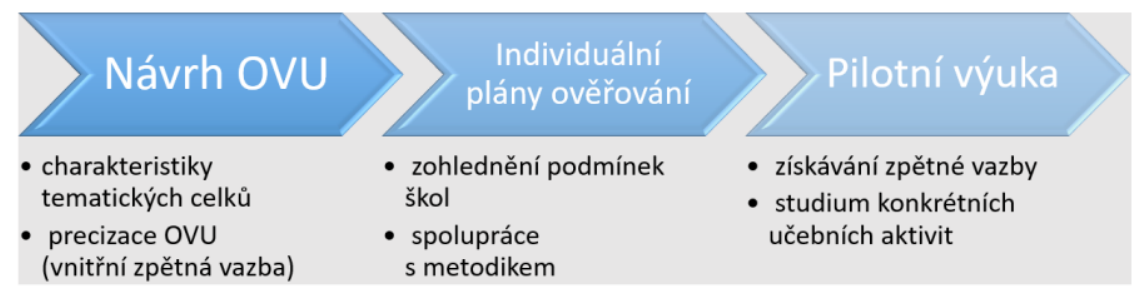

\section{METODICKÁ PODPORA UČITELŮM}

TechnoMet $\sum \begin{gathered}\text { Facebooková } \\ \text { skupina }\end{gathered}>\begin{gathered}\text { Metodické } \\ \text { listy }\end{gathered}>$ DVPP $\quad>\begin{aligned} & \text { Metodický } \\ & \text { portál RVP }\end{aligned}$

\section{METODICKÉ KABINETY - PŘI NPI ČR, PŘíP. PEDAGOGICKÝCH FAKULTÁCH}

Schéma č.1: Průběh pilotního ověrování OVU ve školách

Pro každou ze škol zapojených do projektu byl určen metodik (z většiny pedagogických fakult v ČR), který se školou pravidelně komunikoval a poskytoval jí odborné rady. Vyučující z každé školy na začátku pilotního ověřování posoudili očekávané výsledky učení a zvolili ty, které byly z jejich pohledu na škole ověřitelné. Na základě zvolených očekávaných výsledků učení byly školami vytvořeny individuální plány pilotního ověřování, které byly konzultovány s př́slušným metodikem. Bylo zřetelné, že některé očekávané výsledky učení byly školami s ohledem na aktuální podmínky přjímány více a některé méně. Toto jsou velmi cenné informace s ohledem na formulaci finálních očekávaných výsledků učení zařazených do dalšího roku pokusného ověřování. 
Volbu jednotlivých očekávaných výstupů učení pro pilotní ověřování prováděly na základě vlastního uvážení školy samotné. Zohledňovaly při tom realizační možnosti dané místními podmínkami. Skutečnost, že si některý z očekávaných výstupů učení volily méně často, vypovídá o tom, že pro jeho realizaci školy nemají vhodné podmínky nebo ho nepokládají za významný pro žáky.

\section{Kličová kritéria uplatňovaná při návrhu OVU:}

- maximální volnost škol v rámci realizace výuky - prostor pro profilaci škol a individualizaci výuky,

- vytvoření prostoru pro uplatnění kreativního př́stupu učitele (učitele inspirujeme a vedeme, nicméně ho nesvazujeme),

- $\quad$ kompetenční pojetí s cílem omezení faktografie,

- $\quad$ propojení se životem - vyplývající z charakteristik tematických celků.

OVU jsou formulovány tak, aby jich bylo možné dosáhnout v libovolných podmínkách:

- využití libovolných materiálů, přírodnin, recyklovaných materiálů, polotovarů, stavebnic...,

- ve školní dílně, v běžné učebně, venku, ve sdílené dílně, v dílně stř̌ední školy, sciencecentru...,

- výukou vedenou vlastním učitelem, s využitím outsourcingu...

Na základě poznatků získaných $\mathrm{v}$ rámci pilotního ověřování lze $\mathrm{v}$ souladu s posledním návrhem očekávané výstupy učení rozčlenit do následujících 4 tematických celků:

\section{a) Technika a její význam v životě člověka}

Děti/žáci se seznamují se světem techniky a poznávají význam techniky v životě člověka. Na základě zkušenostního učení, podnětného zkoumání a aktivního provádění pokusů rozvijí schopnost tvořivě myslet a řešit technické problémy blízké každodennímu životu. Osvojené dovednosti, poznatky a návyky vhodně propojují do souvislostí a využívají je při zvládání běžných životních situací, v průběhu dalšího studia nebo v souvislosti s budoucím pracovním uplatněním. Tvưrčí představy děti/žáci vyjadřují a komunikují v podobě náčrtů, plánků, popisů postupů a multimediálních sdělení (především video-návodů) prezentovaných $\mathrm{v}$ tištěné podobě nebo prostřednictvím digitálních technologií. Významnou součástí je taktéž rozvoj porozumění existující dokumentaci za účelem praktického provádění technických aktivit a zhmotnění tvůrčích představ dítěte/žáka.

Precizované očekávané výstupy učení pro pokusné ověřování v roce 2020/21:

1. hodnotí základní technické poznatky a tvořivě přistupuje $\mathrm{k}$ řešení technických problémů z běžného života,

2. využívá prostředky technické komunikace při řešení běžných životních situací.

\section{b) Činnosti s technickými materiály}

Děti/žáci se seznamují s různými postupy a učí se volit a využívat vhodné technické materiály, nástroje a pomůcky. Těžiště činností s technickými materiály spočívá v rozvoji 
psychomotorických dovedností (zručnosti) a pozitivním ovlivňování postojů k pracovním činnostem. Děti/žáci řeší přiměřeně náročné technické úlohy s využitím celého spektra technologií, od tradičních až po nejmodernější, vždy v závislosti na daných podmínkách školy. Výsledky učení směřují do dvou úrovní - roviny činnostní a roviny produktové, které jsou pojímány jako rovnocenné. V rovině emotivní je kladen důraz na prožívání radosti z provádění technických činností i výsledků své vlastní práce, což vede k podpoře technických zájmů.

Precizované očekávané výstupy učení pro pokusné ověřování v roce 2020/21:

1. používá materiály při technických činnostech s ohledem na jejich vlastnosti,

2. ovládá základní způsoby zpracování technických materiálů,

3. zhotovuje výrobky $\mathrm{z}$ technického materiálu s využitím tradičních a digitálních technologií.

\section{c) Konstruování a robotika}

Děti/žáci propojují poznatky z různých oblastí, poznávají, jak věci fungují a jak jsou konstruovány. Provádějí montážní a demontážní práce za účelem pochopení principů, přitom se učí pečlivosti, trpělivosti a jsou vedeni k dokončení činnosti. Konstruují smysluplné celky, které slouží ke konkrétnímu účelu. S ohledem na pronikání robotizace a autonomních systémů do každodenního života i řady povolání, jsou děti/žáci seznamováni se světem robotiky, elektroniky, automatizace. Děti/žáci konstruují produkty přiměřené úrovni jejich znalostí a dovedností a využívají při tom vhodné konstrukční prvky, které vzájemně propojují. K tomu jsou z počátku využívány stavebnice, později přecházejí $\mathrm{k}$ tvưrčímu konstruování, včetně využívání senzorů. $\mathrm{V}$ rámci mezipředmětových vztahů žáci využijí znalosti z oblasti programování.

Precizované očekávané výstupy učení pro pokusné ověřování v roce 2020/21:

1. využivá konstrukční dovednosti v běžném životě,

2. sestaví a uvede do provozu robotické zařízení.

\section{d) Technologie v domácnosti a na zahradě}

Děti/žáci jsou vedeni k osvojování znalostí, dovedností a postojů nezbytných pro řešení situací spojených s fungováním bytu, domu a zahrady, případně i stavby pro relaxaci. Děti/žáci se v kontextu různých životních situací a s ohledem na udržitelný rozvoj učí prakticky navrhovat optimální řešení vlastního bydlení z hlediska dispozic, volby stavebních materiálů a technických instalací, včetně činností spojených se zahradou pro účely relaxace a užitku. Žáci se seznamují i se základy fungování tzv. chytré domácnosti a zahrady.

Precizované očekávané výstupy učení pro pokusné ověřování v roce 2020/21:

1. provádí činnosti spojené s provozem a údržbou bytu a domu,

2. navrhuje nebo volí optimální variantu objektu pro bydlení nebo relaxaci,

3. pečuje o zahradu s využitím vhodného nářadí a moderních technologií. 
Lze si povšimnout, že počet očekávaných výstupů učení byl výrazně redukován tak, aby měly školy dostatečnou volnost v rámci vlastní profilace, avšak př́i současném zachování „návodného“ charakteru, aby se školy „,neztrácely“ při tvorbě ŠVP a $\mathrm{v}$ obsahovém naplnění výuky. Volba konkrétního učiva je plně v pravomoci škol. Jelikož by mohly být vymezené očekávané výstupy učení vnímány jako příliš obecné, byly formulovány specifičtější kompetence, viz KOMPETENCE (2020).

Zpětná vazba v souvislosti s naplňováním očekávaných výstupů učení byla získávána prostřednictvím on-line systému, který je dostupný na adrese: http://www.technika. upol.cz/. Pro uživatele byl zpracován manuál k jeho používání a metodici včetně učitelů pilotních škol byli proškoleni ohledně jeho užívání.

\section{Učitelé zajišt'ující rozvoj technického myšlení a technické tvořivosti na základních školách}

Tak jako v jiných vyučovacích předmětech lze usuzovat, že kvalitní výuku zajistí vyučující s př́slušnou kvalifikací. Setkáváme se rovněž se situacemi, kdy i nekvalifikovaný (neaprobovaný) učitel na základě svých životních zkušeností realizuje výuku, která rozvíjí technické myšlení a tvořivost na velmi vysoké úrovni.

Neaprobovaní učitelé pilotních škol mají vesměs kvalifikaci k výuce matematiky, informatiky, tělesné výchovy, výpočetní techniky, fyziky, výtvarné výchovy, dějepisu, občanské výchovy, př́rodopisu, chemie, zeměpisu, českého jazyka a anglického jazyka.

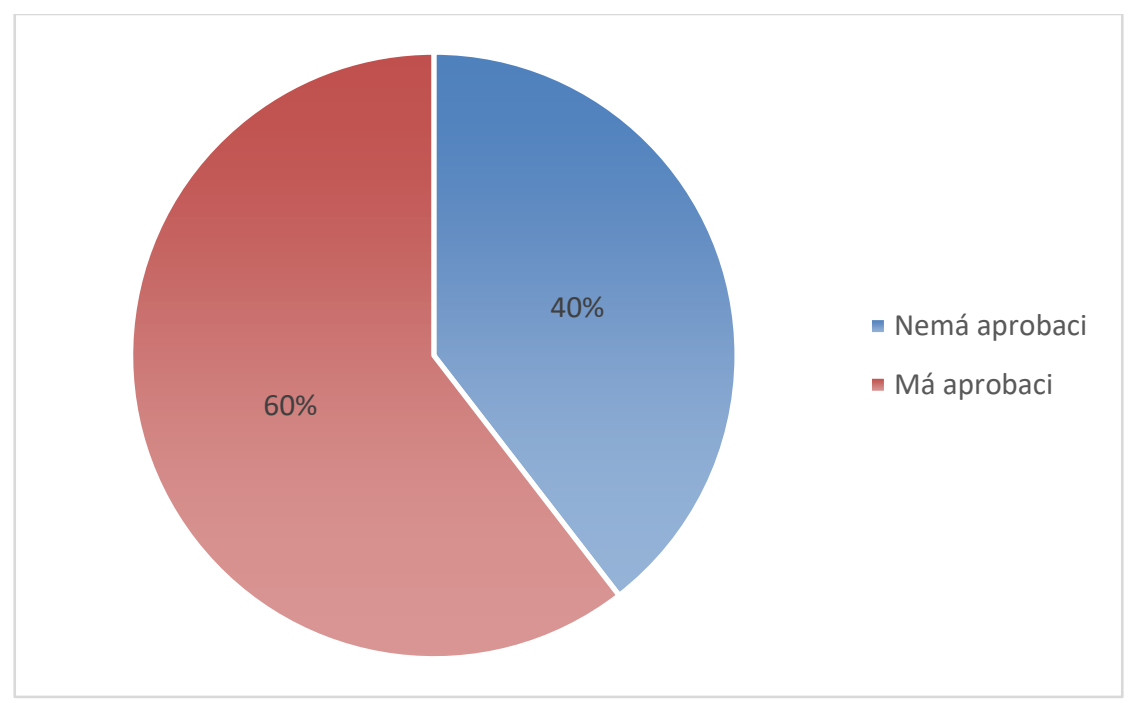

Graf. č. 3: Aprobovanost učiteli̊ pilotnich škol

Systematickou připravu aprobovaných učiteli̊ zajištují následujíci vysoké školy:

- Pedagogická fakulta Univerzity Palackého v Olomouci 
- Pedagogická fakulta Západočeské univerzity v Plzni

- Pedagogická fakulta Masarykovy univerzity v Brně

- Pedagogická fakulta Univerzity Hradec Králové

- Pedagogická fakulta Ostravské univerzity

- Pedagogická fakulta Jihočeské univerzity v Českých Budějovicích

S ohledem na situaci v zahraničí lze konstatovat, že vysokoškolských pracovišt' je v přepočtu na jednoho obyvatele v ČR více, než je jinde obvyklé. Na Slovensku, kde existuje povinně vyučovaný předmět Technika, připravují kvalifikované učitele pouze 3 vysokoškolská pracoviště:

- Pedagogická fakulta UKF v Nitre

- $\quad$ Fakulta prírodných vied UMB v Banskej Bystrici

- $\quad$ Fakulta prírodných vied Prešovskej univerzity

V České republice má př́íprava učitelů techniky dlouholetou tradici - i více než 50 let. Každým rokem proto bez přestání odchází do školské praxe mladí učitelé. Z kapacitního hlediska není problém připravovat i dvojnásobek obvyklého počtu absolventů. Příprava učitelů na fakultách odpovídá nejmodernějším trendům a studenti jsou seznamováni s nejnovějšími technologiemi.

Např́iklad na Univerzitě Palackého jsou učitelé připravování v bakalářském studijním programu „Technika a praktické činnosti pro vzděláváni“ a navazujícím magisterském studijním programu „Učitelství techniky pro SŠ a praktických činností pro ZŠ“،. Platí, že učitel pro SŠ je oprávněn kvalifikovaně vyučovat na ZŠS.

\section{Závěr}

Optimem pro kvalitní rozvoj kompetencí žáků (technického myšlení, zručnosti) je realizace výuky samostatného předmětu $\mathrm{v}$ každém ročníku druhého stupně ZŠ, tedy 4 hodiny celkem pro 2 . st. ZŠ. Z praktických důvodů je však vhodná realizace dvouhodinové (jednou za 14 dnů) nebo blokové výuky. Př́kladem může být nastavení RVP Slovenska. Podněty pro pokusné ověřvóní v r. 2020/21:

- Provést pokusné ověřování na větším vzorku škol (60).

- Převést několik př́kladných škol z pilotního ověřování do pokusného ověřování (př́klady dobré praxe; inkubátory inovací).

- Několik škol zavázat k ověřování kompletní sady očekávaných výstupů učení.

- Při ověřování očekávaných výsledků učení umožnit kombinaci autonomního rozhodování pokusných škol o konkrétním učivu a zároveň cíleného ověření úloh obsažených v metodických listech.

- Otevřít v limitované podobě (bez podpory metodiků) ověřování všem školám v ČR, včetně umožnění volného využívání vytvořených metodických materiálů.

- Intenzivně pokračovat v tvorbě metodických materiálů a realizaci webinářů.

- Systematicky řešit materiální zajištění pokusné výuky, vč. distribuce materiálu. 
Závěrem samotného článku je třeba uvést, že poznatky v něm obsažené mají akademicko-vědecký charakter a nelze je zaměňovat s oficiálními stanovisky MŠMT.

\section{Poděkování:}

Publikování př́ispěvku bylo podpořeno z projektů IGA_PdF_2020_015 Výzkum faktorů ovlivňujících zájem o studium učitelství technických př̀dmětů a možností implementace ICT do vzdělávání.

\section{Literatura:}

Dixon, R. A. (2013). Trends and Issues in Technology Education in the USA: Lessons for the Caribbean. Caribbean Curriculum. Vol. 21, 2013, 47-79.

Dostál, 2018. Podkladová studie. Člověk a technika. Dostupné na: http://www.nuv.cz/file/3517_1_1/

Dostál, J. (2017). Historie technického a rukodělného vzdělávání na území České republiky v 18. a 19. století. Journal of Technology and Information Education, 2017, roč. 9 , č. 2, s. 31-47. DOI 10.5507/jtie.2017.008.

Dostál, J. (2017). Průmysl 4.0 a Společnost 5.0 - výzvy pro změnu (nejen) technického vzdělávání. Technika a vzdelávanie, 2017, roč. 6, č. 1, s. 49-54.

Dostál, J. (2019). Moudrost rukou aneb K realizaci kvalitní výuky techniky na školách potřebujeme kvalitní učitele. In Trendy ve vzdělávání: Technika, informatika a inovace ve vzděláváni napríč obory. Olomouc: Univerzita Plackého, s. 11-16.

Dostál, J. (2019). Význam začleňování učiva o technice a praktických činnostech do kurikula základních škol. Pedagogika. https://ojs.cuni.cz/pedagogika/article/view/1284

Dostál, J. (2019). Zavádění předmětu Technika v České republice anebo pilotní

ověřování odstartovalo. Časopis Technika a vzdelávanie, 8 , č. 2

Dostál, J., Hašková, A., Kožuchová, M., Kropáč, J., Ďuriš, M., Honzíková, J., Částková, P., Žilková, K., Stebila, J., Uhrinová, M., Bendík, M., \& Fadrhonc, J. (2017). Technické vzdèlávání na základních školách $v$ kontextu společenských a technologických změn. Olomouc : Univerzita Palackého v Olomouci, 2017. 274 s. ISBN 978-80-244-5238-8. Hallstörm, J., Hultén, M., \& Lövheim, D. (2013). The study of technology as a field of knowledge in general education: historical insights and methodological considerations from a Swedish case study, 1842-2010. International Journal of Technology and Design Education. Volume 24, Issue 2, Pages 121-139. DOI 10.1007/s10798-013-9252-x Ingerman, A, \& Collier-Reed, B. I. (2011). Technological literacy reconsidered: A model for enactment. International. Journal of Technology and Design Education. Volume 21, Issue 2, pp 137-148. DOI: 10.1007/s10798-009-9108-6.

KOMPETENCE. (2020). Nově formulované kompetence pro vzdělávaci oblast Člověk a technika. Dostupné na:

https://drive.google.com/file/d/1Xov0s9t738a67bp6iAgaiTA9189JHDEb/view?usp=shari ng

Kropáč, J. (2004). Technika, technické vědy, technická výchova. In Kropáč, J., Z.

Kubíček, M. Chráska \& M. Havelka. Didaktika technických predmètù (vybrané kapitoly). Olomouc: UP.

KTEIV. (2020). TechnoChallenge - technická soutěž pro žáky. Dostupné na: https://www.pdf.upol.cz/ktiv/popularizace/technochallenge/ 
Šetlík, J. (2019). V Praze vzniklo další polytechnické hnízdo. PRAHATV. Dostupné na: https://prahatv.eu/zpravy/praha/praha/11367/v-praze-vzniklo-dalsi-polytechnicke-hnizdo. Šumpersko.net. (2019). Šumperk má svého vitěze soutěže TechnoChallenge. Dostupné na: https://zpravodajstvi.sumpersko.net/Sumperk-ma-sveho-viteze-soutezeTechnoChallenge-13697/clanek 